\title{
MALAY LITERATURE IN \\ SINGAPORE: LINES OF \\ THOUGHT AND CONFLICTING \\ IDEAS
}

\author{
Azhar Ibrahim \\ mlsai@nus.edu.sg
}

Department of Malay Studies, National University of Singapore,

Singapore.

\begin{abstract}
A line of thought exists and develops from the socio-political and cultural atmosphere, apart from the writer's level of public and individual awareness. Beginning with the call for "literature for society" by ASAS' 50 , the following decades saw more variety in literary trends, although, on the whole, established writers still remained committed to use literature as a means for raising awareness and channelling social criticism, while at the same time using it to present the ideal to which the writer aspires. In the cultural and political context of Singapore, there are three lines of thought. The first is a kind of foregrounding, in which the writer makes a universal observation of humankind and/or describes the condition of the Malay community with all its challenges and problems, touching on issues that have a basis in history or current realism. The second is the tendency to offer alternatives or echo moral messages that call for people to be more spiritual and more ethical in this life, without making a concrete link to the communal life or the structures and systems that underlie the society and nation. The third is a kind of escapism, indicated by a domestication of thought or "popularization" of literature following the dictates of a market in which light reading and entertainment-type reading materials are what sells. In Singapore today, writing is becoming more varied. What is to be observed is how literature has become the vehicle for refuting dominant ideas, apart from becoming the ground for competing ideas as writers present what they feel is the best idea in the interest of society. The challenge for developing an effective
\end{abstract}


literary culture is ensuring that literary works have a clear social vision, employing good techniques and language skills, while at the same time building a grounded, people-oriented literature. This discussion will analyse the obstacles that complicate the literary culture of the Malay literature of Singapore as it aims to achieve all this.

Keywords: modern literature, Singapore Malay, political culture, humanity, conflicting ideas

The first duty of the native poet is to see clearly the people he has chosen as the subject of his work of art. He cannot go forward resolutely unless he first realizes the extent of his estrangement from them...It is not enough to try to get back to the people in that past out of which they have already emerged; rather, we must join them in that fluctuating movement which they are just giving a shape to, and which, as soon, as it has started, will be the signal for everything to be called in question.

(Frantz Fanon)

\section{INTRODUCTION}

The development of Malay literature in Singapore has a long history. In the tradition of classical Malay literature, Singapore has long been mentioned as an ancient city predating even the Melaka (Malacca) Sultanate. Since the founding of Singapore in 1819, which subsequently witnessed the emergence of and the introduction of printing technology, it has made a big impact on the development of Malay literature.

The city of Singapore became the place where the intelligentsia and activists of the region in the fields of politics, religion, language, literature and the arts, came and stayed. ${ }^{1}$ Before Kuala Lumpur became the centre of Malay literature and culture, Singapore had long been the centre of Malay literature, culture, publishing and journalism, and Malay intellectuality, especially with the establishment of the Malay Studies department at University of Malaya in Singapore. With the post-Independence period and the subsequent secession of Singapore from the Federation of Malaysia in 1965 began a new phase in Malay literature in Singapore. The Malay literature of Singapore is important in order to understand the development of Malay thinking in the republic, especially where ideas, values, aesthetics and involvement are concerned. Literature, apart from the Malay language and Islam, is also capable of strengthening the bond of the Malay community 
with its regional neighbours. In Singapore itself, Malay literature is one of the main elements that characterizes Malay identity.

The discussion of the development of thought in the Malay literature of Singapore is a part of appreciating literature as a document of culture, poetic and literary skill. A line of thought encompasses the perceptions and word view of the writer, including the style of writing that each employs. At times the style is more interesting than the content of the writing, while there are instances when interesting and important themes are found in works in which the storytelling is ordinary but clear. Thought also includes the aesthetic dimension.

This issue needs to be analysed because it is not only important in order to chart the pattern and perspectives in our literature but also to provide a critical and empathic view to show that there are several angles that have not been fully developed. This then invites us to study the causes for such. If there are several angles in which such perspectives could be further developed, it should be handled wisely, especially by organizations and writers' groups that have the intention of developing literature to a more meaningful level for society, the country and humanity as a whole. This is not an impossibility if we know the scape of literature with all its ideas, and its new shoots that must be minded carefully, as well as those aspects that must be weeded out.

We can quote the wise words of two literary figures who once worked in Singapore, and who wished to see a literature that would be useful for the development of Malay society:

Kesusasteraan bukanlah taman bunga tempat orang sesekali datang berehatrehat menghirup udara segar dalam masa lapangnya. Kesusasteraan ialah rumah dan kehidupan manusia yang berombak dan bergelombang, dengan denyut nafas dan degup jantungnya....Tidak saja manusia mempunyai tujuan dalam hidupnya, kesusasteraan pun mempunyai tujuan. Jika manusia hidup mempunyai tujuan yang diterimanya sebagai suatu tugas, maka kesusasteraan pun mempunyai tujuan dan kewajiban yang disebut sebagai tema dan tugas sastera. Sastera bukanlah hanya sastera semata, tetapi sastera ialah alat untuk mencapai tujuan, iaitu mempertajam pandangan manusia terhadap hidupnya, mempertinggi kesedarannya dan memperkaya jiwa yang keseluruhannya mempertinggi tingkat peradaban manusia.

(Literature is not a park where people go once in a while to relax and breathe fresh air in their free time. Literature is a house, it is human life, which is full of ups and downs, and breath and heartbeat....It is not only people who have aims in life but also literature that has aims. If human beings accept that their 
aims are their task in life, the aims and responsibilities of literature are its themes and tasks. Literature is not merely literature, it is a tool to achieve an aim, it sharpens people's views of their life, it heightens their awareness and it enriches their lives, all of which raises the level of human civilization. $)^{2}$

Overall, these are also the views of the key figures in ASAS' 50 after the secession of Singapore, although the motto "literature for society" changed to "literature/art builds humanity", it is still clearly in line with the aims of literature in the Peninsula, whether expressed by writers or scholar, or observers of literature. ${ }^{3}$

\section{THE LITERARY INTELLIGENTSIA}

Analysing Malay literature in detail is important not only because of the works produced but also because it is the only area filled with thought and aesthetics of the Malay language that is consistently produced and apparent in the public sphere. For a long time, a Malay-educated group dominated Malay literature, including our novelists. This group was on the whole quite well-informed as to the developments in literature on the Peninsula and in Indonesia. However, gradually a new generation of writers appeared, one that was English-educated in the urban atmosphere of cosmopolitan Singapore. This generation was more familiar with the Euro-American literary tradition, or the literature of the Third World, whether through formal education, exposure or interest. This was also the generation of Singapore Malays that had a stronger sense of identity compared to the generation before which identified more with Malaysia and/or Indonesia.

In discussing lines of thought in literature, we have to deal with the literary intelligentsia as a social group, which can be differentiated from religious scholars, the political elite, and professionals. It could be said that the literary intelligentsia, together with the cultural activists and Malay language teachers, were the largest group that used the Malay language, and therefore became determined the development of the Malay language and literature in Singapore. Malay discourse in the field of literature, the arts and culture, was complemented and carried on by this group.

In talking about lines of thought, we must remember that this is a general classification (ideal types) and not a specific thought. It is also incorrect to say that theme is the same as line of thought, because the line of thought should represent the main themes that are found in several works. 
The thought that is to be found in each idea reveals the dominant ideology in the local cultural and artistic thought. This is sufficient to show that an understanding of literature cannot be separate from the context of ideas that exist and develop in a particular society.

A conflict of ideas among writers who follow various literary movements is common in any literary culture but what is obvious is that the conflict of ideas and response between the writer and the dominant ideology is what makes literature an arena for ideas. Therefore, for those who wish to understand the thought of Singapore Malays, literature is an important source to be studied and evaluated.

There are five important issues that must be taken into consideration in discussing lines of thought: (1) to what extent the political and socioeconomic conditions influence the lines of thought in Malay literature?; (2) what the response of Singapore Malay writers to the dominant ideology is? (3) what the main concerns of this group are?; (4) once an idea or value is found, what the unexpressed ideas or values are?; and (5) from the responses, the role and contribution of writers from Singapore should be estimable.

\section{BASES FOR EVALUATING LINES OF THOUGHT}

In any society, there is bound to be the ideal of building a society that is prosperous, just, independent and of dignity, where each member of society is treated as an equal member of society and a human being and is recognized as such. This is what one scholar has termed "decent" society. ${ }^{4}$ When discussion thought in literature, it must be in connection with, among other things, the writer's suggestions and discussions of: (1) people's willpower, shortcomings and abilities, and their qualities; (2) the political, economic, cultural and religious realities that affect their lives; (3) the presence or absence of ideas or values in a society; (4) the basic issues in life such as rights and freedoms, justice, love and family, peace and safety, and ethical, social, historical and aesthetic sensitivity, the environment, and human conscience.

Kassim Ahmad believes that writers are the conscience of a nation, and mentions four points concerning literature that is useful, and which conveys a line of thought. Literature should, among other things: (1 ) depicts the types of people realistically and in detail; (2) enhances people's awareness concerning the state of a society; (3) helps people to unite in order to fulfil their social obligations; (4) leads people to oppose wickedness and champion goodness; (5) depicts people and society in creative ways. ${ }^{5}$ The duty to 
disseminate such thinking in literature is not impossible to fulfil if writers possess intellectual, moral and spiritual rationality and maturity ${ }^{6}$ which, in turn, is not impossible if they live together and empathize with the common man and become their voice. ${ }^{7}$ What is important to him is the awareness of writers (and critics) about ideological oppression, and the passing on of such awareness to the common people, which can be achieved if the idea that we should be "free from politics and ideology" and that we should be neutral in a political environment that emphasizes and sanctions dehumanization is avoided. ${ }^{8}$

The basis for discussing thought comes from sociology, in which an idea is evaluated within a historical context, with the group ideology that underlies it. ${ }^{9}$ The idea that is brought forward (whether accepted to rejected) is a reflection of the values and thought of the group and comes about through the connection and response to the idea, and the group who, in actuality, has different, conflicting interpretations of an idea, in the public sphere. Of course, such conflicting ideas are not stated in an obvious way but are cloaked in literature and presented as a universal, nationalistic, islamist, ethnic and regional idea.

In every society that develops, even if there is a dominant idea, there surely will be others that can be considered as opposing it (dissenting ideas), or ideas that develop in the shadow of the dominant idea (undercurrent ideas). Writers, as members of society, respond to a line of thought, based on the belief that has formed in their thinking and experience. The question is why one line of thought develops and continues to exist, while others do not. It is certainly difficult to refute that a good work can be evaluated as such if it displays and contains ideas that are constructive, as Masuri SN once said:

... adalah menjadi kewajipan kita para sasterawan terus membina ketangkasan daya fikir yang positif, yakni yang senantiasa siap sedia dan cuba mengungkapkan pandangan-pandangan kritis, tetapi jitu, bernas, segar dan membina agar dapat mengatasi kehiruk-pikukan, keterburuan yang semata-mata mengejar kenikmatan lahir...

(... it is our responsibility as writers to build a dexterity of thought that is positive-one that is ever ready and attempts to express critical points of view, but is also exact, meaningful, fresh and constructive in order to overcome the frenzy and haste which comes with merely chasing material pleasures ... $)^{10}$ 


\section{DENUNCIATION AND ANNUNCIATION}

One dimension in evaluating thought is to view it within the larger context, and not separately in the way that the themes of a work are usually discussed separately. Ideally, we should view the pros and cons to find those expressions that can be considered denunciations, that is, those that oppose all kinds of attitudes and ideas that are unjust, destructive, oppressive, an abuse of power, and the like, which are commonly called dehumanizing conditions. On the other hand, there is annunciation-consistently expressing and implementing improvements, reforms, and recognition based on a healthy collective conscious that in turn is the result of an independent legal system and free citizens, to uphold justice, prosperity and equality. It is probably an ideal that denunciation is balanced by annunciation in a literary work.

In the context of modern Malay literature, denunciation and annunciation are found within literary works, although most works tend to bring one rather than the other to the fore. More concretely, this can be seen in modern Malay literature where there are two sides to it, as mentioned above. That the historical setting shapes thought in Malay literature has been observed by a sociologist who compared writers producing works in English and Malay in Malaya and Singapore. According to him, the strengthening of identity among Malay writers causes their works to have a stronger involvement with society.

The Malay language writers...did not possess the self-confidence of their (English) counterparts as far as their economic future was concerned, first in a colonial and later in an ex-colonial society. They were doubly marginalized: in colonial society which held firmly to a social Darwinist view of the hierarchy of non-white races, the "native" Malays were considered close to the bottom; in feudal society the boundary between aristocrats and commoners was clearly demarcated. Hence they were pulled in two directions, one toward a class-consciousness within their community, and the other toward a "race-consciousness" between communities. The effect was that they wrote with a greater sense of deprivation and uncertainty about their condition. Paradoxically, this created a sense of urgency amongst the Malay literati in formulating and asserting Malay identity. ${ }^{11}$

This observation is useful to explain the lines of thought that developed and continued on in the culture of literature, especially in Singapore, although other factors have to be considered as well. 


\section{DOMINANT IDEOLOGY}

In discussing Malay literature, one cannot separate it from the political and cultural atmosphere of multicultural, multilingual Singapore with its rapidlydeveloping economy, from the political culture that has an obviously big impact on the workings of the democratic process, from the voices of civil society with an awareness that there are those who have been neglected in the process of development; of course the Malays fall into this category. The dominant ideology influences literature in two ways. Firstly, it influences the way writers think and the way they evaluate things, whether consciously or not. Secondly, it conditions the response or reaction against the dominant ideology in the form of criticism against it, whether it be in the form of ambivalence or escape from it. The levels of criticism certainly vary among writers. There are those who criticize openly and there are those who do it through metaphors and symbols.

Ideology, as an idea and thought that is applied and brought forward by a certain group, is not merely an abstract but it also influences and conditions the way one thinks, acts, and even one's vision and imagination. The social, cultural, political and economic effects of ideology, among others, cannot be taken lightly. There is no reason to be uneasy about the issue of discussing ideology in literature for fear that this will politicize it. It must be borne in mind that ideology is not exclusive to political rhetoric, but that it is in fact something that one encounters in various fields in life: "ideologi sebagai sesuatu yang benar-benar dilalui kehidupan ini, dalam sastera, musik, lukisan, hubungan sosial tanpa memperdulikan perbedaan antara sastera kanon yang besar dengan bentuk kesenian popular masa kini." 12

Understanding the definition, the method of analysis and the effects of ideology must be emphasized. According to Karl Mannheim, analyzing ideology is of the utmost importance because of "those interpretations of situations which are not the outcome of concrete experiences but are a kind of distorted knowledge of them, which serves to cover up the real situation and works upon the individual like compulsion." ${ }^{\prime 13}$ At the same time, when identifying a certain ideology, it must be evaluated, and we should be able to discern the presence, scarcity or absence of a certain concept or idea within the thought because, "ketidakhadiran sesuatu konsep itu bukan saja menunjukkan ketidakhadiran sesuatu pandangan, tetapi juga ketidakhadiran usaha yang bersungguh untuk menanggapi sesuatu masalah kehidupan yang sedang dihadapi." 14 


\section{OBSERVATIONS AND CAUTION IN EXPRESSION IDEAS}

The rapid process of development, tight political regulations and a fairly "controlled" atmosphere when it comes to speaking out, do not allow for open or obvious criticism in social and political spheres, as such an atmosphere does not give much room for speaking out, especially when several institutions or groups, such as religious bodies, workers' unions and the press, have become "domesticated", while a single-party government has been in power for decades.

However, one area which has remained somewhat "autonomous" is the field of literature and the arts, which are difficult to "domesticate" politically. This suggests that literature and the arts are the strongholds of dissenting voices but it must be explained that compared to other areas that have already been "domesticated", literature is the field of critical voices and cynicism against the dominant ideology, and Malay literature certainly falls into this context. This explains the tendency of writers to choose certain themes, styles and modes of presentation in their works.

Therefore, it is not surprising that we will not find literature that is an overt form of protest, as one would find in Indonesia and Malaysia. Of course there have been attempts but we must also bear in mind acceptance by the general public. There definitely have been several subjects that have clearly been avoided so as not to be seen to be "too political," such as the special right of the Malays that are enshrined in the Constitution, the Malay language as the national language, participation of Malays in the military, the levels of economic achievement and education among the Malays compared to other ethnic groups, as well as job opportunities. It could be that in a controlled political environment, discussing such "sensitive" issues could cause one to be accused of being a chauvinist, which is a dangerous accusation if it is levelled by the authorities.

This raises a number of questions: is this a tendency that comes about as a result of political considerations or is it the effect of repressed voices? Or is this avoidance of bringing up sensitive issues as kind of political maturity, or is it caused by an as yet undeveloped political awareness? Is it because the political and cultural conditions cause writers to tend to be pessimistic, lose hope and not be able to overcome problems, such as emerges in their works? A general opinion by Sharifah Maznah and Shaharuddin Maaruf surmises that, seeing the tendencies in Malay literature in Singapore after separation from Malaysia: 
"The separation of Singapore from Malaysia and the consequent minority status of the Malays had great emotional impact on Singapore Malay writers. Generally the response is one of sadness, bitterness, anger and hurt of being displaced or marginalized politically... The literary writers of the times responded to Malay lag in development and minority status negatively. Instead of instilling hope and optimism through their works, inspiring the Malays to progress, prominent Malay writers mainly expressed pessimism and identity crisis through their works." 15

Perhaps the above view is reasonable, however, it is also reasonable to say that there are nuances of craftsmanship that can differentiate concern to depict a current condition that can be termed "illustration" (although its analysis may not be objective), and "lamentation"-writings that tend only to complain, to accuse others and be scornful of oneself. It is our opinion that it is the latter that more often can be seen than the former. ${ }^{16}$

A depiction of realty aims to explain a condition or situation. Complaining will lead to pessimism, and will hinder a complete awareness and empowerment. The latter can be achieved through critical illustration of an ongoing condition. In the hands of a talented writer, depiction in literature, not only brings events to life but also provides an evaluation of what society is facing. The way things are depicted, however sorrowful and repetitive, are aimed at leaving an impact on the reader concerning the seriousness of problems faced in a society, which call for a real concern. However, it is not extreme to say that pessimism is easier to voice than loud protest.

In fact, even the "strong" voices in fiction can be considered "controlled" because they do not come to the level of loud confrontation. This means that, in this respect, Malay writers, and perhaps other writers in Singapore as well, write with certain tendencies, choose certain themes, and limit the patterns and pace of their works in order not to be too "striking" in their language, especially within a culture of conformity and self-imposed censorship. However, it is not possible for such a large number of writers to think and to act monolithically, it is more likely their responses give rise to several main lines of thought, originating from the dominant ideology that they perceive or wish to refute. In fact, a writer may choose more than one line of thought based on the context and conviction while writing a work. Sometimes a line of thought can be seen quite obviously, only to fade later, and reemerge, as if according to season. At one time, the call for "literature for society" was loud and clear, especially among writers of ASAS ' 50 . However, in the period after ASAS ' 50 , there were other tendencies that came out in literature, although, and channel social criticism through various themes and ways. 


\section{TYPES AND LEVELS OF RESPONSE}

Therefore, in speaking about and elaborating about thought in Singapore Malay literature, what must be taken into consideration is the context of era, the socio-political background, and literary movements that each writer follows. It would not be correct to give a definitive list of the kind of thought. In discussing the lines of thought that appear and develop, three responses by the writers must be mentioned within the context of Singaporean politics and culture. Firstly is the kind of response that is forward, where the writer uses literature as the tool to: (a) express something about humankind that must be realized and perceived universally; and (b) to discuss the condition of Malay society with all its challenges and problems, and its various standpoints. Often, the works produced not only record the lives of the Malay community in Singapore but also offer the author's views and evaluation of the phenomenon or issue that is faced by the Malays, although it is not certain that the issue under scrutiny is complete.

Secondly is a kind of tendency of "sidelining", which can manifest as an alternative or moral-ethical or humanitarian and religious idea, which echoes the message that one should be a spiritual, moral and ethical person in this life without linking it in a concrete manner to the life of the community, or the structures and systems that form the background for the community and country. What stands out among these for example, is that it is the individual sin that is often deplored while the societal sins (such as poverty and other kinds of neglect in a society with an unjust structure) are rarely given attention.

The third response is a kind of escapism indicated by literature of a "popular" nature, which is the result of a number of reasons, among these the domestication of thought to the extent that there no longer exists a real social awareness; the dictates of the market call for light reading and mere entertainment. This is the trend in writing for popular consumption, which is increasingly gaining popularity. This kind of writing activities is praiseworthy, however it is uncertain that such works can stand the test of time. Included in this category is a group that is difficult to comprehend because its works have no clear social vision, or lack craftsmanship, although they are wrought in powerful and resounding language. There is a clear plot in these works but the literary qualities must be questioned. ${ }^{17}$

The first and second responses are those that will receive our attention. In each response, we must be aware that there are several literary movements that can be traced (for example, a leaning to the left or right, cosmopolitanism, 
regionalism, or Islamicism) and it is possible for these to "compete" against one another (quietly or explicitly) to bring their ideas forward. It is only when we are familiar with the types of responses of writers towards the contemporary political and cultural climate can we observe the lines of thought that can be found in: (a) responses that deal with the problems of Singapore Malays or humankind universally; and (b) responses that sideline, usually appearing in works with religious nuances, with influences of Sufism, or that deal with harmony in the family and society, and the like.

\section{Direct Responses}

This kind of responses are more flexible and responsive to the conditions of the time, in the sense that they face problems and challenges rationally, although the quality and level of thinking that is presented differs from one writer to another. It is only certain that within this kind of response one would find a line of thought that is in the manner of concern, but for each writer there can be some overlap with other lines of thought mentioned below. Direct responses like these could be viewed from three angles:

(a) Presenting the problems and suffering of the Malays from various angles.

The discussion of problems faced by the Malays has been explored in various dimensions, and social critique colours several of the major works, to the extent that Budi Darma who closely observed the development of Malay literature in Singapore came to the conclusion that "mengkritik adalah ciri khas sastera Singapura" (criticism is a special feature of Singaporean literature).$^{18}$ Presentations of the poverty that envelop the community to the extent that they have to become involved in immoral activities are touched on in the novel Tak Ada Jalan Keluar (No Way Out) (1962) by Suratman Markasan. Harun Aminurrashid, another familiar figure nowadays, in Simpang Perinang (Chaos) (1966), in which he optimistically presents the tenacity of a Malay family living in poverty who work hard to free themselves from the shackles of poverty. In Minah, Joget Moden (1968), Harun writes empathically about Minah, the dancer, who is easily dismissed as a woman of no moral character, although society does not want to get to know them from up close.

There are also works deal with the breakdown of moral values, such as cohabitation, which is the issue in the novel Mail Mau Kawin (Mail Wants 
to Marry) (1976) and the social hierarchy that still persists, as shown in Syarifah (Sharifah) (1998), both written by Muhammad Ariff Ahmad. More seriously are works that criticize the existence experienced by the Malay community, especially after separation from the federation of Malaysia and the subsequent modernization of Singapore. Suratman Markasan, in his poems, hints at the theme of loss, which is also to be found, among others, in his novel Penghulu yang Hilang Segala-galanya (The Headman Who Lost Everything) (1998) and his poems such as the following:

Di pulau indah ini

Keaslian sudah pudar

Penduduk berbahasa asing

Tanah milik sudah terjual

Di pulau ini

Pencakar langit orang punya

Ladang nanas begitu luas

Cuma tempat mengigit jari

Kisah pulau indah ini

Adalah cerita ulangan

Tanah airku bersama

Yang sudah bertukar rupa.

(On this island

The indigenous has faded

The inhabitants speak a foreign language

The land has been sold

On this island

The skyscrapers belong to others

The wide, wide pineapple fields

You have been frustrated of

He story of this island

Is a repeat

My homeland is the same

That has changed shape.)

Again it pulses within a poem that records the loss of Hawaiian islanders as a mirror to the experience of the Malays as the original inhabitants of Temasek.

The political conditions and the dominant idea in interpreting the history, culture and nationality in Singapore has made our established writers enter the 
field of literature to put forward their perspective, whether to directly criticize or to satirize such as in the short stories "Mondok" (Rat) and "Pancasona" (published in translation as "The Utopia of Pancasona") or futuristic such as is depicted in the novel Tiga Lelaki (Three Men) (2005) by Suratman Markasan. In Suratman's novel, he clearly alludes to the country's politics, where speech and political freedom are curtailed.

The ability to deal with these can be explained with several factors, such as the authors' talent, exposure and condition. Their concern for the problems in society make them choose to express themselves through literature, and this, according to Shahnon Ahmad, has something to do with their awareness of history. Shahnon's explanation should be cited:

Pengarang yang peka dengan persekitaran dan peka terhadap kemanusiaan sama sekali tidak melupakan sejarah; malah sejarah menjadi antara premis yang terpenting dalam proses perjalanan mencipta karyanya. Sejarah itu dieksploitnya setuntas dan seluas mungkin, mencampuradukkan realiti sejarah itu dengan yang non-sejarah, dengan dongengan yang menjadi adat kepada bangsanya sehingga campuran antara realiti dan non-realiti itu melahirkan pula realisme magis... Sebab pegangannya pada sejarah, maka wataknya dan juga dirinya sering bernostalgik, sering merenungi masa silam untuk mencari kejernihan masa kini dan masa depannya...

(The author who is sensitive to his environment and towards humanity cannot forget history; in fact history becomes the most important premise in the process of creating his works. History is to be exploited as completely and as much as possible, the historical reality should be blended with the nonhistorical, with the tales that are well-known among his people, until that blend of reality and non-reality results in magic realism ... Because it has a link with history, his characters and also he himself tend to become nostalgic, often looking into the past to find the clarity of his present and future .... $)^{19}$

(b) Bringing forth a non-dominant version of history or expressing a social memory held by the community.

The field of literature becomes the place for bringing forth history at a time when literary discourse only records the dominant version, while the social version of history rarely is given a place. Since Independence, our writers have used literature as a tool by writing historical novels to inject a nationalistic spirit against colonialism and as an affirmation of the glorious history of our people as pioneered by our ancestors. The historical novels of Harun Aminurrashid are the best examples. ${ }^{20}$ 
The following decades witnessed the arrival of historical works that used as their starting point social memory, the remembered stories that had been passed down orally, with a mix of fact and myth. This we can trace in the very poetic text of the play Wak Cantuk (Wak Cantuk) by A Ghani Hamid. Once again in the novelette Desa Ini Hatiku (This Village is My Heart)(2000), Ghani blends historical events with fiction. Or the nostalgic poems about life in the Malay kampongs, such as "Betapapun Nyanyian Rindunya, si Anak Geylang Serai" (How He Sings Longingly, this Child of Geylang Serai) (1999) by Djamal Tukimin, which is interspersed with reflections on life.

At the hands of Isa Kamari, the depiction of history becomes more complex as it is a combination of the known historical narrative and the social memory while at the same time bringing up several questions that need to be reviewed. His novels Satu Bumi (One Earth) (1998), Atas Nama Cinta (In the Name of Love) (2006), Memeluk Gerhana (published in translation as A Song of the Wind) (2007), Rawa (Rawa)(2009) and Duka Tuan Bertakhta (translated as 1819) (2011) are historical novels that "menawarkan penceritaan sejarah alternatif berdasarkan kisah-kisah individu atau kelompok yang bukan dari golongan berkuasa...tumbuh daripada hati nurani masyarakat yang telah melalui sejarah tersebut" (offer an alternative historical account based on the stories of individuals or groups that are not in authority...that have grown from the conscience of the community which has experienced this history). As a writer, Isa is also aware that novels "memaparkan bagaimana aspek kesedaran sejarah telah disulam dengan aspek kehidupan lain dalam satu paparan naratif berupa novel" (present how the aspect of historical awareness is intertwined with other aspects of life in a narrative presentation that takes the form of a novel.). ${ }^{21}$

When looking at the historical novels of which Harun Aminurrashid was a pioneer, these are only introductions to ancient history, within the context of obtaining and fulfilling independence, so that the Malay reader may be able to gain inspiration from the glorious history of the Malays at a time when the colonial version of history disparaged and denigrated the Malay body and soul. The historical novels of Isa Kamari, on the other hand, are attempts to disseminate an alternative version of history that is different from the accepted dominant version of history that is seen as official and "conventional". What is clear is that using a historical corpus or symbol is a way for Singapore Malay authors are able to speak with a notion of tradition, identity and authority. ${ }^{22}$ 
(c) The Voice of Humanity and the Future of the Community with Intellectualism

The expression of intellect and human ethics as a presentation of Malay common sense. This is often explored by writers, among them Rasiah Halil in her short story "Pertemuan" (Meeting), Saeda Buang in her short stories "Razi" (Razi) and "Ke Puncak Pun Tidak" (Haven't Even Reached the Top). This last short story discusses a philosophy in life which places emphasis on a personal ethics of happiness and completeness as opposed to what is commonly accepted in society and required in religion. Rafeah, the character in the story who considers the "worldy knowledge" she has studied at university as deviant and wants to reject it is told off by her friend Rosnah who has a more balanced view. To her, studying modern knowledge has this aim:

Untuk kemanusiaan. Melaluinya kita mengetahui kekurangan ahklak kita, kekurangan sistem-sistem hidup kita. Melalui teori-teori ini kita tahu di mana kelemahan kita sebagai manusia yang sentiasa tidak puas dan akibat-akibatnya. Aku percaya kita harus cuba cari jalan keluar dengan penemuan-penemuan yang baharu. Melalui teori-teori yang kau katakan sesat ini kita mengetahui rentetan peristiwa yang merugikan manusia akibat naluri-naluri yang tidak terkawal. Dan ini semua dibedah dan dipersembahkan oleh teori-teori ini, lalu kita boleh jadikannya sebagai ikhtibar. Dan ini semua aku yakin adalah ilmu yang boleh dimanfaatkan. Ini satu tuntutan. Bukankah segala usaha yang kita buat demi kebajikan insan itu satu tuntutan agama?

(For humanity. Through it we get to know the shortcomings in ourselves and our system of life. Through these theories we know our weaknesses as human beings who are never satisfied, and all its effects. I believe that we must try to find our way out with new findings. Through the theories that you say are misleading, we can know the chain of events that have made human beings lose out due to their uncontrolled desires. And this is all dissected and presented by these theories, and we can then take them as models. And this I believed are all knowledge that is useful. It is a requirement. Are not all efforts that we make for the good of mankind a requirement in religion? $)^{23}$

This line of thought clearly deals with the theme of literature with a touch of intellectualism, not only because of the way it deals with society but also because it makes use of cultural symbolism interpreted more creatively and critically. For example, Hadijah Rahmat, in her poem "Cerita Rakyat III" (Folk Tale III) says this, among other things: 
Kita

Anak-anak Melayu

bukan si Tenggang durhaka

bukan juga si Malim Kundang durjana

Kita mahu mengakhiri seloka

Mat Jenin, Pak Pandir, Pak Kaduk dan Lebai Malang

Kita perlu cipta sebuah karya agung seni

rakaman dan cerminan sebuah perjuangan

mengorak langkah-langkah cemerlang

menghapus kesesatan

menangkis latah dan gejala rimba

dengan kecanggihan ilmu, wahana dan wawasan waja

dan kentalnya iman dan amal

Kita pacu tenaga dan rebut keunggulan budi dan cita

mengukir citra indah bangsa dan manusia

di panggung jagat raya.

(We

Are the descendants of the Malays

Not those of the disobedient Tenggang

or those of the wicked Malim Kundang

We want to end the comedy

of Mat Jenin, Pak Pandir, Pak Kaduk and Lebai Malang

We need to create a magnum opus

The record and reflection of a struggle

to begin taking great steps

to eradicate nonsense

to ward off hysteria and the ways of the jungle

through knowledge, and a strong vision and way

and a strong faith, and good deeds

We must spur our energies and race for excellence in character and ideals

To carve a beautiful image of our race and our people

on the great international Stage. $)^{24}$

This is echoed by Rasiah Halil in the lines of her poem "Yang Baru Melayu" (Now This is Malay) (2005):

Kitakah orang Melayu baharu

Yang sering terasa malu

Masyarakat \& warisan 
MALAY LITERATURE VOLUME 27 NUMBER 12014

Kitakah orang Melayu baharu

Yang mendabik dengan kebendaan

Sekali gus bernafas keagamaan

Mengisytihar kehebatan

Yang sepuhan \& salutan

Tanpa sedar

Makna sebarang kelebihan

Apakah kita orang Melayu baharu

Atau orang-orang yang baru Melayu

Anak-anak Macaulay

Berkulit coklat, cerah, sawo matang,

Bercelaru menghidupi fahaman borjuis

Aib pada khazanah, warisan,

\& bertingkah dengan minda tertawan?

(Are we the new Malays

Always ashamed

Of our people \& heritage

Are we the new Malays

Proud of our material wealth

In the same breath as religion

Announcing our greatness

Which is merely a veneer $\&$ a gilding

Without realizing

The meaning of any advantage

Are we the new Malays

Or just people who are now Malay

The sons of Macaulay

With brown, light or olive skin,

Confused with bourgeois life

Ashamed of our inheritance, our heritage,

$\&$ acting with colonized minds? $)^{25}$

Even the established poet Masuri SN embellishes his poetry with messages for humankind, and with the hope of creating a civilized human being and community, as can be seen in his poem "Azam Baru" (New Resolution) (1996). 
kehidupan kita sekali ini

Bukan bersorak. Kita mulakan

Sekarang tindak dan gerak

Bukan berputar-putar melingkari

Bulatan yang tak putus-putus.

Pemikiran sekarang telah kita bentuk

Menjadi peta perjalanan

Untuk mencapai

Tujuan dan idaman;

Setiap kita yang terus mengingini

Akan tidak kita lalui lagi;

Kita sekarang berdiri

Menyakini hari muka adalah sari

Kehidupan dunia berwarna seri

Kehidupan akhirat kekal mewangi

(our lives this time

Are not for cheering. We begin

Our actions and movements now

Not turning and turning to draw

An infinite circle.

Our thoughts we have now shaped

To be a travel map

To achieve

Our aims and dreams;

Unfulfilled wishes

We will not go through again;

We now stand

Confident that the future is the essence

of life on Earth, in beautiful colours

That eternally fragrances the afterlife. $)^{26}$

\section{Sideline Responses}

This does not imply that these works are of secondary or lesser quality, rather there is a tendency to write works that do not deal with the problems of society head on; instead, the writer chooses a different approach. Denunciation is not an apparent feature in this line of thought, instead it leans more toward presentation or annunciation. In terms of involvement in literature that discusses societal issues, this line of thought may be backward, but when 
seen from the angle of writing that records experiences and the psyche, then this line of thought becomes significant.

Among such works are those that lean towards the religious such as those works that are called "Islamic literature"; works with sufi tones such as explored by Johar Buang, and works with a strong moralizing tone such as the short stories of Peter Augustine Goh. The annunciating angle is a value an idea that is much stronger in this line of thought. What drives this kind of writing is the effort to produce a stronger soul and faith to face modern life with its distractions. The issue is not whether this emphasis is erroneous, but the content that is suggested.

On the one hand, it refuses to discuss the conditions of the Malay community out of the blue. Even if it attempts to present some issues from the Malay community, it is usually weighed down by the perspective of moral suggestions and a call to return to strong Islamic values. Johar Buang is one poet who consistently has produced poems and short stories with sufi nuances, some of which have to do with asceticism, repentance, the holiness of religious figures and stories in which elements of faith are linked with magical elements. Among the works that can fall into this category are also the poems of A Ghani Hamid that often are set in nature, with its nevertense verses, that nevertheless do not lack deep observations, as in the poem "Antara Penghuni Alam" (Among the Inhabitants of Nature) (1965):

Tapi, mengapa senja menghitam

Melindung tangan-tangan durjana

Meragut dan mencakar alam,

Dan musnah bumi pusaka?

Mereka menoda budi

Menyala pertarungan,

Kami dari kumpulan penghuni

Melukis perdamaian

Lukisan kami mohon cinta

Antara penghuni buana"

(But why intentionally blacken

And protect the evil hands

That rip and scratch nature,

And destroy this Earth, our heritage?

They stain the mind

Ignite battles, 
We are from a group of inhabitants

That draw peace

Our drawing calls for love

Among the inhabitants of the world $)^{27}$

It is not excessive to say that there are works whose language is more resounding but the content and thought contained in it is rather vague and perhaps even impossible to grasp. The limitations of this kind of writing has been observed by a number of literary scholars, such as Sitor Situmorang, who generalizes about the trend of writers such as this in the following words:

Malahan ada hal yang dalam penghargaan sastra kita sekarang, sebagai manusia yang kita sebut saja manusia modern, yang tak dapat kita terima sama sekali; Yaitu kesentimentilan, mengasihani diri sendiri, langsung atau melalui tokoh-tokoh yang dilukiskan, meminta belas kasihan, sembari mengkhotbahi pembaca barangkali. Pernyataan sentimentil, oleh manusia sekarang dianggap urusan privat, dan soal meminta belas kasihan bukan sikap manusia sekarang, yang telah mencapai dan memiliki kesadaran-kesadaran dan pengertian-pengertian lain akan hubungan sosialnya, hubungannya dengan alam, bahkan hubungannya dengan dewa-dewa. Dalam sastra sekarang orang tidak meminta belas kasihan, juga tidak mengajar susila. Sastra sekarang menunjukkan dan menyatakan kesadaran akan kesanggupan manusia mengatasi keadaan dan dirinya.

(In fact, there are things in our appreciation of literature today which we, if we consider ourselves modern human beings, cannot accept at all; that is sentimentality, self-pity-either directly or through the characters depictedevoking pity, while perhaps at the same time lecturing the reader. Sentimental statements are considered today to be a private matter, and asking for pity is not the way of people today, who have achieved and who possess awareness and other types of understanding about social relationships, their relationship with the world, even with the gods. In literature today, no one asks for pity, no one teaches morality. Literature today shows and expresses the awareness of the willingness of people to overcome their condition and themselves. ${ }^{28}$

\section{THE SPIRIT OF SINGAPOREANNESS IN IDENTITY AND PLACE}

The choice of themes in literature comes from an awareness and understanding of the issues and challenges that are faced by a society, and presenting these 
in literature is not something that comes about suddenly or out of nothing. From a culture of literature that is involved, and with critical literary discourse, profound ideas can come together from among writers and literature activists. On the other hand, if literature is merely the place for writing and "filling a space", then substantial ideas will not be able to develop.

One line of thought that can be seen in Singapore Malay literature is about city life. The rapid development of Singapore as a city cannot but invite writers to produce writings about the lives of city-dwellers, or urban literature, something in which Singaporean writers experienced earlier and much faster than writers from other countries in the region. However, if there is a clear and widespread thought that can be identified as urban literature, it has not been completely refined. This dimension should receive the greatest attention in discussion, and how local writers respond to the great change at a time when Singapore is rapidly developing as a city of trade, industry and housing development. The theme of city life often comes up in major works, and is mostly connected to life and destiny.

Singapore Malay literature is the best example to prove how Singapore Malays manifest their Singaporeanness. Today, vernacular literature is considered national literature, that is, it includes Malay, Chinese, Tamil and English literature. It has been said by a scholar that among the ethnic groups in Singapore, those who most closely exemplify a Singaporean identity is the Malay community, seeing as they are the original inhabitants of this island. It is common to find writers who express Singaporeanness as belonging to the Malays just as much as to those other ethnic groups who have long been in the country and only know Singapore as their homeland.

Established Malay writers write a lot about the lives of Singapore Malays, and this can be seen clearly in their novels, short stories and poems. The novel Simpang Perinang (Chaos) (1966), the creation of Harun Aminurrashid, tells about a poor family at the fringes of Singapore, who are fiercely independent in their struggle to escape poverty. We are touched by their destitution but we are also amazed and moved by their attitude of not giving up even in the face of hopelessness. This tale of the resilience of a poor Malay family shows optimism and foresight, apart from a multicultural spirit, and certainly works such as these must be differentiated from works that are full of prejudice and racial stereotyping. ${ }^{29}$

On the same theme of poverty is the novelette by Mohamed Latiff Mohamed, Kota Air Mata (City of Tears) (1977), in which Singapore, with its rapid development, becomes the city of tears for the abject poor. Ani, the protagonist, suffers because there is no money for her schooling; she is worried about paying the examination fees, comes home from school hungry, 
has no comfortable home in which to study her lessons, and faces school teachers who express the common notion that poverty is the fault of the poor themselves. It also shows the ease with which those who are slick and greedy are able to take advantage of those who are weak. Although this novelette can be said to echo pessimism and resignation but it is also a reminder that the dominant structure that causes poverty is also a big obstacle to the escape from poverty, and the mere call for people to "embrace progress" is just an illusion. Latiff, who is always cynical, closes his poem "Kota Kelahiranku" (The City of My Birth) (1976) with these resounding lines:

\section{kota kelahiranku}

Di suatu masa di suatu ketika

Di saat langit merah jingga

Kami akan bangun mengangkat muka

Memandang langit terbuka

Hari ini mengundang kami menjadi lelaki satria

Kota ini melarang kami menitiskan airmata.

(this city of my birth

At one time at one point

At the second the sky was orange-red

We will rise and raise our faces

To look at the open sky

This day invites us to become warriormen

This city forbids us to shed tears.)

The novel Menara (Tower) (2002) by Isa Kamari, is a more contemplative work about the lives of people in the city. The issue is no longer poverty, as in the previous two novels, instead the plot revolves around a talented architect seeking the meaning of life and humanity in the city. An intellectual tone is clearly developed in this novel. The criticism in it is subtle and controlled, with the theme of human isolation in the city that the protagonist faces and overcomes. Encountering a hodge-podge of ideas, city folk may easily confused and perplexed but this is also where seekers are born, as depicted in the character of the architect. It also represents a great number of young, educated people who are tossed between embracing modernity and traditions that are relevant for life in the present:

Buat pertama kali aku bertembung dengan berbagai falsafah hidup. Aku selami bermacam-macam pemikiran ciptaan manusia yang kebanyakannya 
bercanggah dan menyerang jiwaku. Akibatnya aku terpeleset di atas jubin falsafah licin kerana aku tidak membersihkan niatku. Pegangan agamaku menjadi goyah. Pemikiranku berbaur dan kacau. Aku tidak tahu mana yang benar, mana yang palsu.

(For the first time I encountered different types of philosophies in life. I delved into many types of human thought, most of which were contrary to mine and attacked my soul. As a result, I faltered on the slippery floor of philosophy because I had not corrected my intention. My religious faith was shaken. My thoughts were befuddled and unsettled. I did not know what was right and what was wrong.) $)^{30}$

Here is the human voice of the Singapore Malay, who wishes to rise up and be on par with the others, as expressed in this novel: "Kerana aku pernah diinjak, jiwaku bangun dengan tujuan membuktikan kepada masyarakat yang meminggirku bahawa aku mampu bertahan, malah berjaya" (Because I was once trodden down, my soul rose up with the aim of proving to those who had sidelined me that I was capable of holding on, of succeeding, even.) $)^{31}$ This is the self-worth of a person or community. City-dwellers, who live their lives in constant isolation, are considered by Isa to be "manusia takut berhadapan dengan wajahnya sendiri" (people who are afraid to face their own faces). ${ }^{32}$

Malay identity is not only linked to language, religion and culture but also to place, whereby Malays feel that the place they live in-a modern, progressive city-will shape their identity and future. Surely there are writers who mourn the loss of kampongs all over Singapore when the process of urbanization is in full swing. What we can observe is a loss of place, in fact the names of the new places are clearly alien. This is expressed by Mohd Latiff Mohd in "Potret Singapura" (A Portrait of Singapore) : "terbayang Geylang Serai/dan Kampung Wak Tanjung/menjadi Ang Mo Kio/Pek Ghee dan Yishun" (it brings to mind Geylang Serai/and Kampong Wak Tanjung/ that have become Ang Mo Kio/Pek Ghee and Yishun.) In "Di Kota Ini” (In This City) (1980), Latiff waxes nostalgic

di kota kosmopolitan

yang tiada lagi irama dondang sayang

tiada lagi sorak-sorai

mendaulatkan "bahasa kebangsaan.

in this cosmopolitan city

where there is no longer the melody of dondang sayang 
there is no longer the cry

hailing the "national language".

In the novel Batas Langit (The Sky's Limit), Latiff echoes the insecurity of Singapore Malays who will be the citizens of a republic after secession from Malaysia, apart from depicting the chaos of the poor in Singapore, whose lives are tempest-tossed. The trauma and anxiety of the Malay community after the separation-a subject that is rarely spoken about openly-is clearly depicted in this novel. In the same way, Suratman has wrought a poem about Singapore as a city, recording the mournful cries of those who have been uprooted from their homes: "Aku kehilangan lautku/Aku kehilangan bukitku/ Aku kehilangan diriku" (I have lost my sea / I have lost my hills /I have lost myself.)

\section{Aku tak punya apa lagi}

Sri Lanang dan Nila Utama tinggal nama

Saudagar peribumi menolak bahasa

Mengejar Inggeris lambang kemajuan

Puisi prosaku kurang dibaca

Tak juga sastera dunia."

Singapuraku

aku mengerti sekali

di sini tempatku

tapi aku tidak tahu bila

aku akan menemui segala kehilanganku?

(I have nothing left anymore

Sri Lanang and Nila Utama are just names now

The indigenous traders refuse their language

Chasing English, the symbol of progress

My poems and prose are rarely read

Not being world literature."

My Singapore

I truly understand

this is my place

but I do not know when

I will find all that I've lost? ${ }^{33}$ 
What we can surmise from this is the mourning over a loss of place that is often found in the works produced by Malay writers. Does such a complaint mean that there cannot exist a kind of Malay humanity in city life, in line with the passage of time and its open challenges? Surely this is not impossible if we have the foresight to develop something new, preserve what exists and leave behind what is outdated.

\section{CONCLUSION}

Mapping the lines mentioned above is tracing the main lines of thought in the Malay literature of Singapore that continues to grow. ${ }^{34}$ Surely much more can be said about the tenor, style and beat of the writings produced. If observed within the literary genres, it appears that poetry is the more flexible, clearer and wider medium for us to come to a conclusion about the lines of thought in Singapore Malay literature. Another things is that technical skill can also be taken into consideration, as it has an impact on the developing line of thought. For example, a vague narrative technique will make it difficult to convey an idea through a creative work. Or it can happen that if too much attention is placed on creating a unique narrative technique, that an idea cannot be formed substantively in the work.

There are several obstacles to developing a strong literary culture capable of generating concise critical and creative thinking, while at the same time empowering and instilling the hope for goodness and perfection. This would require a long elaboration, but thus far, allow us to extract several factors that may be a cause. Among these is (1) a fading idealism-a spirit of involvement that is not longer at the forefront; (2) a blunting of awareness in the context of political neutrality, positivism in academic thinking and spreading neutrality and ambivalence; (3) dogmatism and moralism that colours the thinking of the writer, or (4) a manner of thinking that is not organic and concerned with this world, that is otherworldly, with the care for the unseen world and the afterlife overcoming all else; (5) language that has become domesticated by a backward awareness to the extent that no concepts arise in the thinking; (6) critical discourse is not developed to the extent that it can contribute to the awareness and appreciation of literature among writers and the public; (7) the dictates of the market that call for light reading, to the extent that writers with potential opt for this type of writing.

Finally, in discussing the aspects of thinking that can be found in our literature, there is the opportunity to develop a progressive literary culture, anchored on a healthy mind, and reaching a high level of aesthetic but still 
intelligible level of expression, as well as being empowering and raising a spirit of universal humanity. This literary culture should itself be in the process of becoming, supported by the dynamics of factor, context and actor. Progressive though in literature can only emerge when writers make a big commitment towards producing works that are closely connected with society and its humanity. Therefore, it is fitting to conclude with Keris Mas's observation that: "Masalah penulis yang wujud sepangjang zaman- dahulu dan sekarang-ialah masalah mempertajam persepsi, mempertajam fikiran, mempertajam sensitiviti serta mengenal manusia dan masyarakat" (The problem of writers throughout the ages is that of sharpening their perception, their thinking, their sensitivity; and to know mankind and society). ${ }^{35}$

\section{NOTES}

$1 \quad$ Ismail Hussein, 1955. "Pengarang2 Melayu di Singapura Selepas Perang Dunia II (1945-1958). Latihan Ilmiah, Jabatan Pengajian Melayu, Universiti Malaya, Singapura,

2 Usman Awang \& A. Samad Said, 1963. Tema dan Tugas Sastera Melayu Moden. Singapore: Federal Berhad.

3 For example, S. Husin Ali states: "Sastera yang membicharakan tentang keadaan dan chita2 rakyat jelata yang terbanyak boleh diperluas dan dipopularkan dikalangan mereka sendiri. Ini penting. Sastera bukan se-mata2 untuk menghibur, tetapi ia juga bertugas untuk menimbulkan kesedaran dikalangan rakyat - kesedaran tentang segala kenyataan serta kebenaran mengenai diri mereka dan tentang apakah arah perubahan yang harus mereka tuju dan ikuti untuk mendapatkan pembebasan dan keadilan yang tulen bagi diri mereka." (Literature that discusses the situation and aspirations of the public at large can be expanded upon and popularized among them. This is important. Literature is not only entertainment, it also has the duty to raise awareness among the public-awareness of all statements and truths about themselves and about what their direction of change should be in order to achieve freedom and true justice for themselves). Suara Tujuh. (Kuala Lumpur: Setia Murni, 1969), p. 4

4 According to Avishai Margalit, decent society, is "one whose institutions do not humiliate people....A civilized society is one whose members do not humiliate one another, while a decent society is one in which the institutions do not humiliate people...A decent society is one that fights conditions which constitute a justification for its dependents to consider themselves humiliated. A society is decent if its institutions do not act in ways that give the people under their authority sound reasons to consider themselves humiliated. Refer to, The Decent Society. ( Cambridge: Harvard University Press, 1996), p. $1,10-11$

5 Kassim Ahmad, 1979. Dialog Dengan Sasterawan. Kuala Lumpur: Pena, p. 95-6.

6 Kassim Ahmad, 1979. Dialog Dengan Sasterawan. Kuala Lumpur: Pena, p. 43.

7 Kassim Ahmad, 1979. Dialog Dengan Sasterawan. Kuala Lumpur: Pena, p.70.

8 Kassim Ahmad, 1979. Dialog Dengan Sasterawan. Kuala Lumpur: Pena, p. 86.

9 Alexander Kern, 1970. "The Sociology of Knowledge in the Study of Literature," in Milton C. Albercht, et al., (eds.), The Sociology of Art and Literature: A Reader. London, 
Duckworth.

10 Masuri SN, 1998. Kreativiti dan Kemanusiaan dalam Kesusasteraan. Shah Alam: Fajar Bakti, p. 41.

11 Lian Kwen Fee, 2001. "Absent Identity: Post-War Malay and English Language Writers in Malaysia and Singapore," in Tong Chee Kiong et al. (eds.), Ariels: Departures \& Returns, Essays for Edwin Thumboo. Singapore : Oxford University Press, p. 209.

12 Stanley Aronowitz, "Politics and Higher Education in the 1980's" in Journal of Education, p. 48-9.

13 Mannheim, From Karl Mannheim, 1993. Kurt H. Wolff, (ed.) (New Brunwick, N.J: Transaction Publishers, p.105

14 Karl Mannheim, 1976. Ideology and Utopia. London: Routledge \& Kegan Paul, p. 246

15 Shahruddin Maaruf, 2000. "Singapore Malay Literature," in Budi Darma, (ed.) Modern Literature of ASEAN. ( Jakarta: ASEAN Committee on Culture and Information, p. 111, 115

16 The term "illustration" used here is taken from Paulo Freire who says it is "a process of knowing reality, how reality is made. The more you understand the mechanisms of economic oppression and exploitation, the more you understand what working for wages really is, the more you illuminate, the more you put light on some obscurity necessary for domination." See Ira Shor and Paulo Freire, 1987. A Pedagogy for Liberation: Dialogues on Transforming Education. Wesport: Bergin \& Garvey, p. 45.

17 The same observation was made by Suratman Markasan, From the beginning to two streams of social critique = Dari Jalan Permulaan ke Dua Jalur Kritik Sosial. (Singapore: [S. Markasan], 1991).

18 Budi Darma, 2000. "Suratman Markasan: Sastera Melayu Singapura," in Suratman Markasan -70 Tahun. Singapore: Haji Hashim, p. 350. Budi Darma, 2000. "Suratman Markasan: Sastera Melayu Singapura,” in Suratman Markasan -70 Tahun. (Singapore: Haji Hashim, p. 350.

19 Shahnon Ahmad, 2013. "Apalagi kalau Bukan Keperihalan Kemanusiaan," in Hamzah Hamdani (ed.), Citra dan Visi Sastera Melayu. Kuala Lumpur: DBP, p. 46.

20 Panglima Awang (1959), Anak Panglima Awang (1961) Dayangku Fatimah (1967), Peristiwa Laksamana Cheng Ho ka-Melaka (1969)

21 Isa Kamari, "Sastera dan Kesedaran Sejarah: Mengisahkan Kembali Ceritera Singapura." Presented at CITA. Organized by the Malay Studies Department of NUS and The Arts House, 24 March 2012

22 An observation mentioned by Mana Sikana, Sastera Singapura dan Malaysia di Era Pascamoden. ( Singapore: Persama, 2003)

23 Sa'eda Buang, 2012. "Ke Puncak Pun Tidak," in Melangkaui Jambatan Kedua: Cerpen Terpilih Dari Malaysia \& Singapura. KL: ITMB, National Arts Council, p. 200.

24 Hadijah Rahmat, 1998. Di Tengah Alam. Kuala Lumpur :DBP, p. 34-35.

25 Rasiah Halil, 2013. Nyanyian si Anak Dagang. Kuala Lumpur: DBP, p. 143.

26 Masuri SN, 2003. Suasana Senja: Kumpulan Sajak, 1995-2001. Singapore: ASAS50', p.33.

27 A Ghani Hamid, 1987. Nota. Singapore: ASAS 50', p. 5.

28 Sitor Situmorang, 2004. Sastra Revolusioner: Esai-Esai. Yogyakarta: Matahari, p. 265

29 Read Hadijah Rahmat, 2003. "Lukisan Sastera Melayu- Antara Keunggulan dan Kenyataan," in M Pitchay Gani (ed.) Pertemuan Sastera Nusantara XII: Sastera Melayu 
Warisan Jati Diri dan Jagat. Singapura ASAS' 50 \& NLB.

30 Isa Kamari, 2002. Menara. Singapore: Pustaka Nasional, p.52.

31 Isa Kamari, 2002. Menara. Singapore: Pustaka Nasional, p. 53

32 Isa Kamari, 2002. Menara. Singapore: Pustaka Nasional, p.3

33 Suratman Markasan, 2004. Puisi Luka dan Puisi Duka. Singapore: Pustaka Nasional, p. 16.

34 Azhar Ibrahim, 2011. "Perkembangan Novel-novel Melayu Singapura (1965-2009) Imbasan Awal" in Juffri Supa'at (ed.), Bibliografi Sastera Melayu Singapura (19652009). Singapore: National Library Board, p. 558-562.

35 A Karim Haji Abdullah (ed.), 1997. Mutiara Fikir Sasterawan Negara Keris Mas. Petaling Jaya: Pustaka Budaya, p. 22.

\section{REFERENCES}

A Ghani Hamid, 1987. Nota. Singapore: ASAS 50'.

A Karim Haji Abdullah, (ed.), 1997. Mutiara Fikir Sasterawan Negara Keris Mas. Petaling Jaya: Pustaka Budaya.

Avishai Margalit, 1996. The Decent Society. Cambridge: Harvard University Press. Azhar Ibrahim, 2011. "Perkembangan Novel-novel Melayu Singapura (1965-2009) Imbasan Awal," in Juffri Supa'at (ed.), Bibliografi Sastera Melayu Singapura (1965-2009). Singapore: National Library Board.

Budi Darma, 2000. "Suratman Markasan: Sastera Melayu Singapura," in Suratman Markasan -70 Tahun. Singapore: Haji Hashim.

Hadijah Rahmat, 1998. Di Tengah Alam. Kuala Lumpur: DBP.

Hadijah Rahmat, 2003. "Lukisan Sastera Melayu- Antara Keunggulan dan Kenyataan," in M Pitchay Gani (ed.) Pertemuan Sastera Nusantara XII: Sastera Melayu Warisan Jati Diri dan Jagat. Singapore: ASAS'50 \& NLB.

Isa Kamari, 2002. Menara. Singapore: Pustaka Nasional.

Isa Kamari, 2012. "Sastera dan Kesedaran Sejarah: Mengisahkan Kembali Ceritera Singapura.” Presented at CITA. Organized by the Malay Studies Department of NUS and The Arts House, on 24 March 2012.

Ismail Hussein, 1955. "Pengarang2 Melayu di Singapura Selepas Perang Dunia II (1945-1958). Latihan Ilmiah, Jabatan Pengajian Melayu, Universiti Malaya, Singapura.

Kassim Ahmad, 1979. Dialog Dengan Sasterawan. Kuala Lumpur: Pena.

Kern, Alexander, 1970. "The Sociology of Knowledge in the Study of Literature," in Milton C. Albercht et. al., (eds.), The Sociology of Art and Literature: A Reader. London, Duckworth.

Lian, Kwen Fee, 2001. "Absent Identity: Post-War Malay and English Language Writers in Malaysia and Singapore," in Tong Chee Kiong et al. (eds.), Ariels: 
Departures \& Returns, Essays for Edwin Thumboo.Singapore : Oxford University Press.

Mana Sikana, 2003. Sastera Singapura dan Malaysia di Era Pascamoden. Singapore: Persama.

Masuri SN, 1998. Kreativiti dan Kemanusiaan dalam Kesusasteraan. Shah Alam: Fajar Bakti.

Masuri SN, 2003. Suasana Senja: Kumpulan Sajak, 1995-2001. Singapore: ASAS 50'. Mannheim, Karl From Karl Mannheim, 1993. Kurt H. Wolff, ed. New Brunswick, N.J: Transaction Publishers.

Mannheim, 1976. Karl Ideology and Utopia. London: Routledge \& Kegan Paul. Rasiah Halil, 2013. Nyanyian si Anak Dagang. Kuala Lumpur:DBP.

Sa'eda Buang, 2012. "Ke Puncak Pun Tidak," in Melangkaui Jambatan Kedua: Cerpen Terpilih Dari Malaysia \& Singapura. Kuala Lumpur: ITMB, National Arts Council.

S. Husin Ali, 1969. Suara Tujuh. Kuala Lumpur: Setia Murni.

Shahnon Ahmad, 2013. "Apalagi kalau Bukan Keperihalan Kemanusiaan," in Hamzah Hamdani (ed.), Citra dan Visi Sastera Melayu. Kuala Lumpur: DBP. Shahruddin Maaruf, 2000. "Singapore Malay Literature," in Budi Darma, (ed.), Modern Literature of ASEAN. Jakarta: ASEAN Committee on Culture and Information.

Shor, Ira \& Paulo Freire, 1987. A Pedagogy for Liberation: Dialogues on Transforming Education. Westport: Bergin \& Garvey.

Sitor Situmorang, 2004. Sastra Revolusioner: Esai-Esai. Yogyakarta: Matahari. Suratman Markasan, 2004. Puisi Luka dan Puisi Duka. Singapore: Pustaka Nasional. Suratman Markasan, 1991. From the Beginning to Two Streams of Social Critique /Dari Jalan Permulaan ke Dua Jalur Kritik Sosial. Singapura.

Usman Awang \& A. Samad Said, 1963. Tema dan Tugas Sastera Melayu Moden. Singapore: Federal Berhad. 